\title{
Biomass and morphology of fine roots in temperate broad-leaved forests differing in tree species diversity: is there evidence of below-ground overyielding?
}

\author{
Catharina Meinen · Dietrich Hertel • \\ Christoph Leuschner
}

Received: 18 June 2008 / Accepted: 2 April 2009 / Published online: 5 May 2009

(C) The Author(s) 2009. This article is published with open access at Springerlink.com

\begin{abstract}
Biodiversity effects on ecosystem functioning in forests have only recently attracted increasing attention. The vast majority of studies in forests have focused on above-ground responses to differences in tree species diversity, while systematic analyses of the effects of biodiversity on root systems are virtually non-existent. By investigating the fine root systems in 12 temperate deciduous forest stands in Central Europe, we tested the hypotheses that (1) stand fine root biomass increases with tree diversity, and (2) 'below-ground overyielding' of species-rich stands in terms of fine root biomass is the consequence of spatial niche segregation of the roots of different species. The selected stands represent a gradient in tree species diversity on similar bedrock from almost pure beech forests to mediumdiverse forests built by beech, ash, and lime, and highlydiverse stands dominated by beech, ash, lime, maple, and hornbeam. We investigated fine root biomass and necromass at 24 profiles per stand and analyzed species differences in fine root morphology by microscopic analysis. Fine root biomass ranged from 440 to $480 \mathrm{~g} \mathrm{~m}^{-2}$ in the species-poor to species-rich stands, with $63-77 \%$ being concentrated in the upper $20 \mathrm{~cm}$ of the soil. In contradiction to our two hypotheses, the differences in tree species diversity affected neither stand fine root biomass nor vertical root distribution patterns. Fine root morphology showed marked
\end{abstract}

Communicated by Amy Austin.

C. Meinen $\cdot$ D. Hertel $(\bowtie) \cdot$ C. Leuschner

Plant Ecology, Albrecht-von-Haller-Institute for Plant Sciences,

University of Göttingen, Untere Karspüle 2,

37073 Göttingen, Germany

e-mail: dhertel@gwdg.de distinctions between species, but these root morphological differences did not lead to significant differences in fine root surface area or root tip number on a stand area basis. Moreover, differences in species composition of the stands did not alter fine root morphology of the species. We conclude that 'below-ground overyielding' in terms of fine root biomass does not occur in the species-rich stands, which is most likely caused by the absence of significant spatial segregation of the root systems of these late-successional species.

Keywords Below-ground · Biodiversity ·

Niche complementarity

\section{Introduction}

The majority of studies investigating the biodiversityfunction relationship in grasslands found an increase in above-ground productivity with plant species diversity or diversity of plant functional types (e.g., Tilman et al. 1996; Hooper and Vitousek 1997; Hector 2001; Hector 2001; Schmid et al. 2001; Dybzinski et al. 2008). One explanation of such 'overyielding' of species-rich stands is a more pronounced niche complementarity as compared to species-poor communities or even monocultures (Parrish and Bazzaz 1976; Hector et al. 1999; Hector 2001). While the vast majority of studies on diversity effects on productivity was carried out in grasslands or other herbaceous communities (Tilman et al. 1996; Hooper and Vitousek 1997; Hector et al. 1999; Joshi et al. 2000; Spehn et al. 2000; Loreau and Hector 2001), the functional role of tree species diversity has only recently been investigated in more detail. The few studies investigating tree species diversity effects showed contradictory results (Pretzsch 2005). Some 
authors report overyielding effects in mixed compared to single tree species communities (e.g., Morgan et al. 1992; Brown 1992; Bauhus et al. 2000; Erskine et al. 2006), while others found no effect of tree species diversity on biomass accumulation and productivity or even negative effects (Smith and Long 1992; Yanai 1992; Enquist and Niklas 2001; Vila et al. 2003; Szwagrzyk and Gazda 2007). Most of these studies compared monocultures with two-species mixtures. The recently established tree plantations with stands differing in tree species diversity are in most cases too young to allow for sound conclusions on the diversity-productivity relationship (Scherer-Lorenzen et al. 2005, 2007).

In addition, the majority of the cited investigations have focused on the above-ground responses alone. Thus, little is known about the effects of tree species diversity on structure and function of the below-ground organs of trees. Moreover, a convention on the use of the term 'overyielding' for the below-ground component of trees does not exist. This is particularly unsatisfactory since the fine root system of trees is a functionally highly important compartment of forest ecosystems (e.g., DeAngelis et al. 1981; Fitter 1996). Fine roots are not only responsible for water and nutrient uptake, but also represent an important component of the ecosystem carbon cycle (Keyes and Grier 1981; Fogel and Hunt 1983; Jackson et al. 1996; Schlesinger 1997). One reason for the obvious lack of studies on the relationship between tree species diversity and root system structure and dynamics is the difficulty of distinguishing between the fine roots of different species. In fact, we know of only one study that investigated the structure of the fine root systems of more than two tree species in temperate deciduous forests, based on a morphological determination key for identifying the fine roots of different species (Hölscher et al. 2002). The bulk of root studies in mixed forests also referred to two-species stands (review in Leuschner and Hertel 2003) and searched for biomass differences as compared to monospecific stands and for evidence of vertical root stratification among species as an effect of root competition (Hertel 1999; Morgan et al. 1992; Schmid 2002). In several cases, a higher total fine root biomass in mixed compared to monospecific stands was found (Berish and Ewel 1988; Cuevas et al. 1991; Schmid and Kazda 2002), while other studies found fine root biomass to be unaffected by the presence of an allospecific below-ground competitor (Bauhus et al. 2000; Leuschner et al. 2001).

Trees could not only respond to the presence of one (or more) competing tree species by changes in fine root biomass and its spatial distribution, but also with modification of fine root morphological traits such as specific root area (SRA) or branching patterns. For example, studies of Lohmus et al. (1989) and Ostonen et al. (2007) showed that fine root morphology can be highly plastic in response to different nutrient availabilities. Whether the fine root morphology of trees responds to the presence of roots of other tree species is not yet clear.

This study investigated structural properties of the fine root system of deciduous forests with low, modest, and high tree species diversity, which grow in close neighborhood to each other under similar edaphic and climatic conditions. Based on previous work, we were able to identify tree fine roots by species and thus analyze the exploration of the below-ground environment by different tree species quantitatively. We tested the hypotheses that (1) stand fine root biomass increases with tree diversity thus indicating 'below-ground overyielding', and (2) 'overyielding' of species-rich stands in terms of fine root biomass is the consequence of spatial niche separation of different species in the soil. Study objectives were (1) to quantify stand fine root biomass in 12 forest stands with either one, three, or five dominant tree species, (2) to analyze the contribution of the different tree species to total fine root biomass and to search for species differences in root:shoot ratios, (3) to assess the evidence for spatial niche differentiation below-ground, and (4) to quantify differences in fine root morphological traits between the species and to study possible differences which might be caused by different levels of tree species diversity.

\section{Materials and methods}

\section{Study site description}

The study was conducted in a species-rich deciduous forest in the Hainich National Park, Thuringia, Germany. This national park is one of the largest unfragmented broadleaved forests in Europe. It contains areas of different levels of tree species diversity due to differences in forest management strategies in past centuries. For selecting the study plots, the whole area of the national park was screened for possible study plots that met the following criteria: (1) the stands should be dominated by either one, three, or five tree species (with European beech being present at variable densities in all stands), (2) all plots being mature stands with the trees of the different species in the age of maximum productivity ( $80-150$ years), (3) comparable above-ground stand structure in terms of basal area and dbh, (4) similar climate conditions, and (5) comparable soil conditions in terms of geological substrate (Triassic limestone covered by Pleistocene loess), similar soil texture, and comparable thickness of the mineral soil profile depth above the bedrock. The selection procedure resulted in about 20 possible sites that met these criteria sufficiently. In this sample, the 12 study plots $(50 \mathrm{~m} \times 50 \mathrm{~m})$ which fulfilled these criteria best were selected representing three diversity levels (DL 1, DL 2, DL 3) with each four plot replicates. Maximum 
distance between the study plots was ca. $5 \mathrm{~km}$, mean minimum distance was about $420 \mathrm{~m}$, which excluded direct interference between neighboring stands in terms of water and nutrient fluxes or microclimate.

Plots of diversity level 1 were dominated with a minimum of $95 \%$ of the total basal area by Fagus sylvatica L. DL 2 plots were characterised by Fagus sylvatica (mean of $60 \%$ of total basal area), Tilia species (Tilia cordata Mill. and/or Tilia platyphyllos Scop., 6\%) and Fraxinus excelsior L. (22\%). DL 3 plots included five main tree species: Fagus sylvatica (19\%), Tilia species (18\%), Fraxinus excelsior (18\%), Carpinus betulus L. (12\%) and Acer species (Acer pseudoplatanus L. and/or Acer platanoides L., 4\%). Other tree species, e.g., Quercus robur, Quercus petraea, Prunus avium and Ulmus glabra, are found occasionally in some of the DL 3 plots. The marked differences in tree species composition of the stands are not primarily a result of different soil or climate conditions (which were mostly minimized by our strict selection criteria), but rather originated from different forest use practices in past centuries. Forest plots of the more diverse categories DL 2 and DL 3 were in former times managed by other landowners that applied a more intense forest use than those owning the DL 1 stands, leading to the establishment of more diverse stands. However, all stands have been subjected to only extensive forest use in the past ca. 50 years and no management at all has occurred since the national park was established in 1997.

The DL 2 and DL 3 plots were characterized by a dense herb layer with a cover of about $80 \%$, while the herb layer cover in the DL 1 plots was somewhat lower with $60 \%$ (Table 1). Mean tree age ranged from 80 to 120 years in the DL 2 and DL 3 plots; the beech trees in the DL 1 plots were somewhat older at about 146 years. All stands had a closed canopy and similar basal areas (ca. 36$42 \mathrm{~m}^{2} \mathrm{ha}^{-1}$ ). All plots were located at an elevation of $350 \mathrm{~m}$ a.s.l. The mean annual temperature is $7.5^{\circ} \mathrm{C}$ and annual precipitation is $670 \mathrm{~mm}$ (data of the nearby weather station Weberstedt/Hainich). The soils in the study area developed from a loess cover over Triassic limestone and were classified as luvisols (FAO taxonomy 2006) with stagnic properties in spring and winter and a dry period in summer. The soil texture of the mineral soil $(0-30 \mathrm{~cm})$ showed high silt $(\mathrm{ca} .74 \%)$ and low sand $(<5 \%)$ contents (Guckland et al. 2009). At $0-10 \mathrm{~cm}$ depth, $\mathrm{pH}$ $\left(\mathrm{H}_{2} \mathrm{O}\right)$ was about 6.0 or higher in the DL 2 and DL 3 plots, but tended to be lower in the beech-dominated DL 1 plots. As a consequence, base saturation ranged from ca. 60 to 99\% in the six DL 2 and DL 3 plots, but was lower in the DL 1 plots (Table 1). A ca. 4-cm-thick organic layer existed in the DL 1 plots, while only $1-2 \mathrm{~cm}$ of mull-type leaf litter was present in the DL 2 and DL 3 plots in spring and summer, and was mostly decomposed until the end of the summer.
Table 1 Characteristics of above-ground stand structure and soil chemical parameters of the 12 study plots in the diversity levels (DL) $1-3$

\begin{tabular}{lccc}
\hline & DL 1 & DL 2 & DL 3 \\
\hline Stand characteristics & & & \\
Basal area $\left(\mathrm{m}^{2} \mathrm{ha}^{-1}\right)$ & $41.6 \pm 2.4$ & $38.8 \pm 2.6$ & $35.9 \pm 1.8$ \\
Mean tree age $($ years $)$ & $146 \pm 16$ & $89 \pm 5$ & $106 \pm 4$ \\
Stem density $\left(n\right.$ ha $\left.^{-1}\right)$ & $272 \pm 52$ & $601 \pm 74$ & $419 \pm 35$ \\
Mean tree height $(\mathrm{m})$ & $35.9 \pm 1.1$ & $28.5 \pm 0.5$ & $26.6 \pm 0.3$ \\
Canopy cover $(\%)$ & $85.8 \pm 1.1$ & $91.1 \pm 0.5$ & $89.9 \pm 1.3$ \\
Herb cover in spring $(\%)$ & $61 \pm 16$ & $83 \pm 2$ & $79 \pm 2$ \\
Soil chemical parameters & & & \\
pH (H $\left.{ }_{2} \mathrm{O}\right)$ 0-10 cm & $5.1 \pm 0.2$ & $6.1 \pm 0.1$ & $6.6 \pm 0.1$ \\
C/N ratio 0-10 cm & $16.9 \pm 0.5$ & $13.8 \pm 0.3$ & $14.4 \pm 0.3$ \\
Base saturation $(\%) 0-10 \mathrm{~cm}$ & $32.3 \pm 12.9$ & $73.6 \pm 6.1$ & $88.0 \pm 5.9$ \\
\hline
\end{tabular}

Given are means \pm SE for four plot replicates per diversity level

Data on basal area, stem density, mean tree height of canopy trees, and canopy cover were provided by Brauns (unpublished), mean tree age of canopy trees by Schmidt (unpublished), herb cover and $\mathrm{pH}$ values by Mölder et al. (2006, 2008), C/N ratio and base saturation by Guckland et al. (2009)

Soil sampling and root analysis

Root sampling was conducted in each three transects of $30 \mathrm{~m} \times 1 \mathrm{~m}$ per study plot that were randomly placed in the $50 \mathrm{~m} \times 50 \mathrm{~m}$ plots. Each eight sampling locations per transect were randomly chosen resulting in 24 coring locations per plot. Minimum distance between two sampling locations was $1 \mathrm{~m}$ in order to avoid mutual disturbance through coring. Soil coring was conducted at each location (one sampling date in 2005 or 2006) in the soil profile to $40 \mathrm{~cm}$ depth (including the organic layer) with a steel corer $3.5 \mathrm{~cm}$ in diameter. The cores were sliced into four sub-samples of $10 \mathrm{~cm}$ length each. The samples were stored in plastic bags at $5^{\circ} \mathrm{C}$ and processed within 6 weeks. For analyzing the fine root mass (diameter $\leq 2 \mathrm{~mm}$ ), the samples were soaked in water and cleaned from soil residues using a sieve (mesh size $0.25 \mathrm{~mm}$ ). Fine root fragments longer than $1 \mathrm{~cm}$ were collected by hand with a pair of tweezers, separated into live and dead fractions using a stereomicroscope and sorted by species. For separating live and dead root fractions, morphological criteria such as root elasticity, the degree of cohesion of root stele and periderm, and the presence or absence of the stele were used (Persson 1978; Leuschner et al. 2001). For species identification, a classification system based on morphological attributes, such as surface structure and color of the periderm, ramification pattern, and type of mycorrhizal infection was used. This identification key is based on fine root material of different species extracted in the rhizosphere of isolated individuals where species identification 
was undoubted. Part of the key has been successfully applied in earlier mixed forest studies (e.g., Hölscher et al. 2002). Herb and grass roots were distinguished from tree roots by the lack of visible suberinization, their lighter color, and smaller diameter. Tree fine roots $\geq 1 \mathrm{~cm}$ in length represent the most important fraction of the living fine root mass in soil samples, while a large part of the dead fine root mass consists of root fragments smaller than $1 \mathrm{~cm}$ in length (Bauhus and Bartsch 1996; Hertel 1999). To record this fraction of dead rootlets, a method introduced by van Praag et al. (1988) and modified by Hertel (1999) was applied to one-sixth of all samples. After extraction of the root fragments $>1 \mathrm{~cm}$ from these samples, the soil residue was evenly spread on a large sheet of filter paper $\left(730 \mathrm{~cm}^{2}\right)$ subdivided into 36 squares. Six of the squares were randomly selected and all dead root material was collected under a stereomicroscope. For estimating total fine root necromass of a sample, a regression analysis on the dependence of the $<1 \mathrm{~cm}$ fraction of dead root mass on the $>1 \mathrm{~cm}$ fraction was calculated to extrapolate from the $>1 \mathrm{~cm}$ fraction to the total necromass. The fine root biomass and fine root necromass samples were dried at $70^{\circ} \mathrm{C}$ for $48 \mathrm{~h}$ and weighed. Both biomass and necromass were expressed as dry matter per square meter of ground area per soil depth interval and as soil profile total (unit: $\mathrm{g} \mathrm{m}^{-2}$ ). For estimating the fine root mass in the lower profile (below $40 \mathrm{~cm}$ soil depth), the exponential root distribution model introduced by Gale and Grigal (1987) was applied to the fine root density in the data in the $0-40 \mathrm{~cm}$ profile. The equitation $y=1-\beta^{d}$ describes the vertical decrease in fine root density with increasing soil depth, with $y$ expressing the cumulative fine root fraction in the soil from the surface to the soil depth $d$ (in $\mathrm{cm}$ ). High $\beta$ values (ca. 0.98) indicate a large proportion of fine root biomass in a deeper soil depth, low $\beta$ values (ca. 0.90) indicate a large proportion of fine roots near the soil surface. The $\beta$ values were calculated individually for each tree species present in the 12 plots.

One living root branch per species of each sample and soil depth was scanned for analysis of root surface area and mean root diameter. Digital images were analyzed with the computer software WinRhizo 2002a (Régent, Quebec, Canada). Specific fine root surface area (SRA, $\mathrm{cm}^{2} \mathrm{~g}^{-1}$ ) was calculated from the dry weight of the respective root branch and its surface area. Root area index (RAI, square meter root surface area per square meter ground area) was obtained by multiplying fine root biomass with specific fine root surface area of the respective sample. In addition, the number of root tips was counted under the stereomicroscope. This data was used to calculate specific root tip abundance (number of tips per mg dry weight or number of root tips per square meter stand area).

In order to quantify the contribution of roots of the herbaceous plants to the total fine root mass of the stands, this root mass fraction was investigated in one plot per diversity level according to the method described above. Herb roots were sampled at four sampling dates (April, June, September 2006 and January 2007) to cover the pronounced seasonality in herb biomass. These labor-intensive investigations had to be restricted to the three plots DL 1a, DL 2c, and DL 3a.

\section{Statistical analyses}

All data were tested for Gaussian distribution using a Shapiro-Wilk test. The majority of the datasets showed a non-Gaussian distribution and could not satisfyingly be transformed. Therefore, a non-parametric Mann-Whitney $U$ test was used to detect significant differences between different samples $(P<0.05)$. This test was carried out with the software package SAS, version 8.2 (SAS Institute, Cary, NC, USA). The linear regression fits and the nonlinear cumulative root distribution model after Gale and Grigal (1987) were computed with the software package Xact, version 8.03 (SciLab, Hamburg, Germany).

\section{Results}

Living and dead fine root mass

Total fine root biomass showed no significant differences between the almost pure beech plots (DL 1) and the plots dominated by three (DL 2) or five tree species (DL 3) (Fig. 1a). In all plots, fine root biomass decreased markedly with soil depth with $64-77 \%$ being located in the upper $20 \mathrm{~cm}$ of the soil. Fine root necromass also did not differ significantly between the three diversity levels, but DL 3 plots tended to hold less fine root necromass than DL 2 and DL 1 plots (Fig. 1b). The bulk of fine root necromass was also found in the upper $20 \mathrm{~cm}$ of the soil (72-79\%).

The contribution of root biomass of herbaceous plants to the fine root mass totals of the plots was only marginal. In the DL 1a and the DL 2c plot, only 1.0 and $1.1 \%$ (i.e., 4.3 and $5.3 \mathrm{~g} \mathrm{~m}^{-2}$ ) of the fine root biomass total was contributed by herb roots (data not shown). The plot with highest tree species richness (DL 3a) showed a significantly higher herb fine root biomass than the DL 1a and DL 2c plots. However, despite a herb cover of $80 \%$ in DL 3a, only $3.9 \%$ (i.e., $19.2 \mathrm{~g} \mathrm{~m}^{-2}$ ) of the total fine root mass belonged to herbs.

Regression analysis showed that total fine root biomass $(0-40 \mathrm{~cm}$ soil depth) was not significantly related to the number of tree species present, above-ground stand structure, or soil chemical properties. Fine root biomass in the upper $10 \mathrm{~cm}$ of the soil, on the other hand, positively correlated with the number of tree species, base saturation, and 


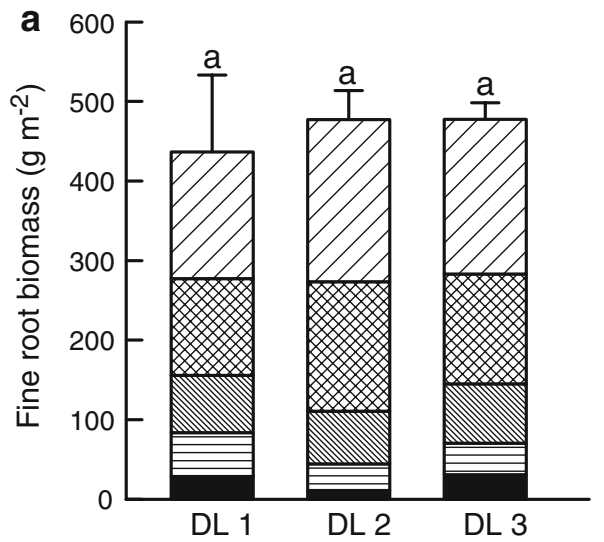

Fig. 1 Fine root biomass (a) and fine root necromass (b) in different soil layers of forest plots of three diversity levels $(D L)$. Given are means \pm SE from each four replicate plots per diversity level $(n=24$ sampling locations per plot). Different letters indicate significant differ-

the $\mathrm{pH}\left(\mathrm{H}_{2} \mathrm{O}\right)$ in this soil depth, but not with stand structural parameters (Table 2). However, tree species diversity and soil chemistry explained only $22-32 \%(r=0.47-0.57)$ of the variation. In contrast, fine root necromass of the total soil profile $(0-40 \mathrm{~cm})$ or of the upper $10 \mathrm{~cm}$ of the soil was not significantly influenced by any of these parameters (data not shown).

Although mean fine root biomass $(0-40 \mathrm{~cm})$ per ground area showed no significant differences between stands differing in tree diversity, fine root biomass in samples from the topsoil $(0-10 \mathrm{~cm}$ depth) was significantly higher when four species were present in a soil sample as compared to less diverse samples (Fig. 2). Soil samples with one, two, or three root species present did not significantly differ with respect to fine root biomass.

Species contribution to stand fine root biomass

The proportion of Fagus fine roots in total fine root biomass decreased strongly from the DL 1 to the DL 3 plots while that of Tilia, Fraxinus, and Acer increased (Fig. 3). In the

Table 2 Results of linear correlation analyses relating stand structural and soil chemical variables measured at the 12 plots to fine root biomass in the upper $10 \mathrm{~cm}$ of the soil

\begin{tabular}{lll}
\hline Source & $r$ & $P$ \\
\hline Number of dominant tree species & 0.51 & $<0.05$ \\
Basal area $\left(\mathrm{m}^{2} \mathrm{ha}^{-1}\right)$ & 0.08 & $\mathrm{NS}$ \\
Stem density $\left(n \mathrm{ha}^{-1}\right)$ & 0.62 & $\mathrm{NS}$ \\
Base saturation $(\%)$ & 0.47 & $<0.05$ \\
$\mathrm{pH}\left(\mathrm{H}_{2} \mathrm{O}\right)$ & 0.57 & $<0.05$ \\
\hline
\end{tabular}

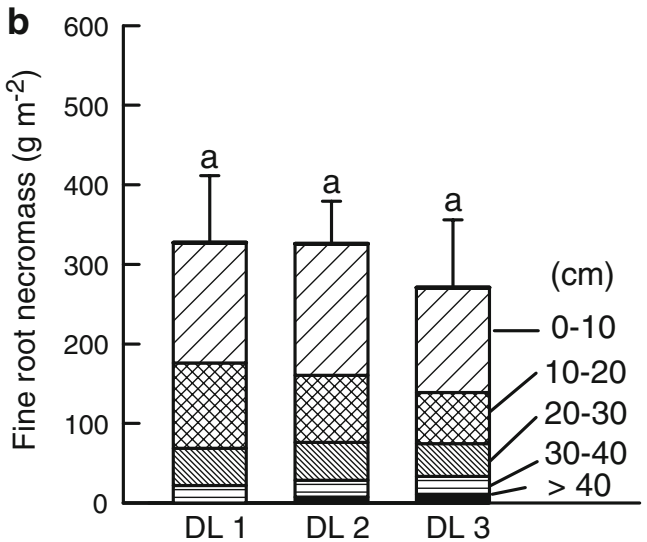

ences between diversity levels; $P<0.05$. The fine root biomass below $40 \mathrm{~cm}$ soil depth was estimated with the depth distribution equation for roots of Gale and Grigal (1987) parameterized for the tree species of this study

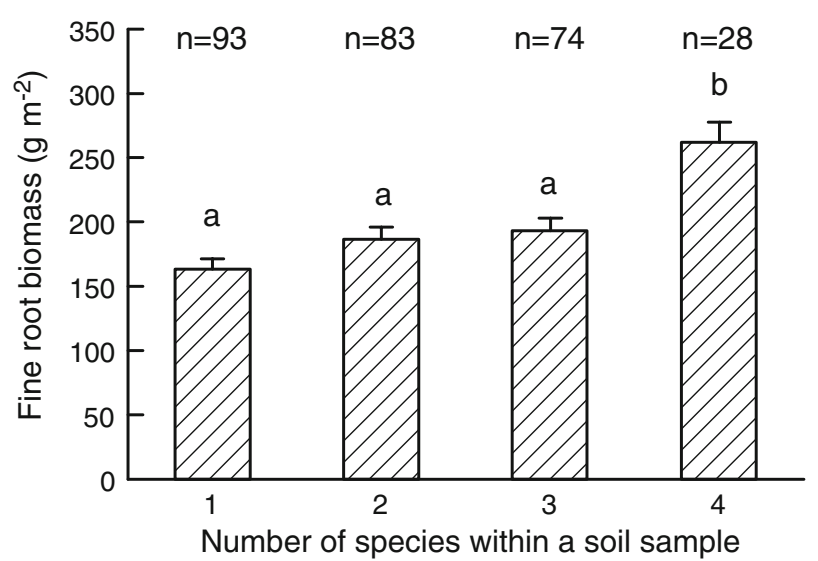

Fig. 2 Fine root biomass in the upper soil $(0-10 \mathrm{~cm})$ as dependent on the number of tree species present in the soil samples of the 12 forest plots. Given are means \pm SE. Different letters indicate significant differences between the four classes; $P<0.05$. Note that the species combination of fine roots in a soil sample may vary within a given class of number of tree species

DL 3 plots, fine roots of Fraxinus and Tilia were the most abundant species, followed by Acer, Carpinus, and Fagus.

Comparison of the above-ground abundance of the species (expressed as a species contribution to total stand basal area) with their abundance in the root samples revealed imbalances. The ratio of percent fine root biomass to percent basal area was $>1$ for Fraxinus and Tilia in the DL 2 plots, thus indicating higher below-ground than aboveground abundances, whereas Fagus and Acer were underrepresented in the soil (Table 3). In the DL 3 plots, the highest relative below-ground abundance was found for Fraxinus and Acer. Tilia and Carpinus showed similar abundances above- and below-ground, while Fagus (and other, more rare species) was markedly more abundant above-ground than below-ground. 


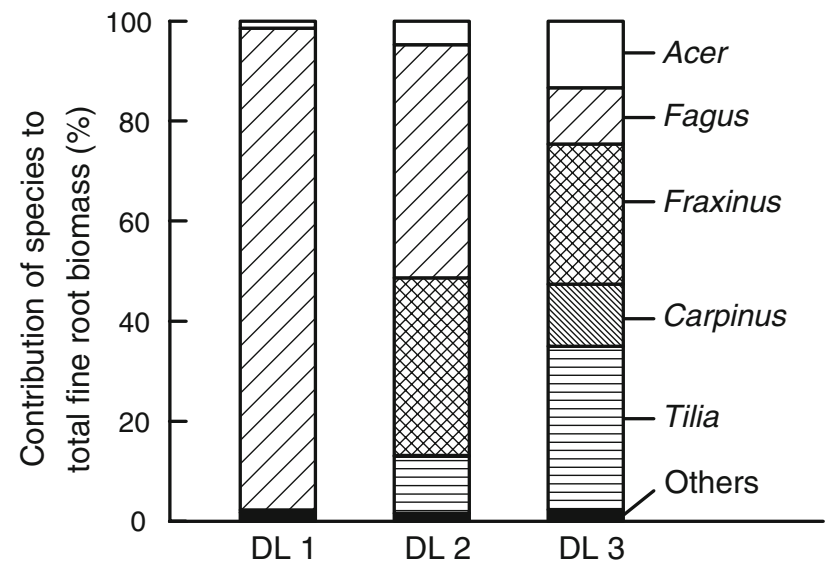

Fig. 3 Contribution of the different tree species to the profile totals ( 0 $40 \mathrm{~cm}$ ) of fine root biomass in forest plots of the three diversity levels $(D L)$. Given are the means of each four replicate plots and 24 sampling locations per plot. Others refers to Acer campestre, Prunus avium, Ulmus glabra, and Quercus sp.

The ratio of living to dead fine roots was $>1$ in all stands and species and showed no significant differences between species or diversity levels (Table 3). However, there was a tendency for living Fagus fine roots to increase with increasing tree species diversity. All species tended to show highest live to dead root ratios in the most tree species-rich stands of DL 3.

Vertical fine root distribution of the species

The vertical fine root distribution pattern of the different species in the soil was very similar in all study plots. The extent of fine root biomass decrease with soil depth as indicated by the $\beta$ values of the applied regression equation showed no statistically significant differences among species or diversity levels (Table 4). An exception was found for Acer sp. in the DL 2 plots, which showed a particularly strong decrease in fine root biomass with soil depth. Maximum $\beta$ values reached 0.95 as in the case of Carpinus in the DL 3 plots. However, most of the tree species revealed $\beta$ values in the range of $0.92-0.94$ in the plots of the three diversity levels, hence indicating a rather strong decrease in fine root biomass density with soil depth of all species present in the plots.

Fine root morphology of the species

Root morphological parameters differed significantly among the species, but differences of a species between the three diversity levels were rarely found (Table 5). Specific root tip abundance was lowest (about three tips $\mathrm{mg}^{-1}$ ) in Fraxinus and ranged from 20 to $60 \mathrm{mg}^{-1}$ in the other species. Fagus showed a significantly higher specific root tip abundance in the DL 2 compared to the DL 1 and DL 3 plots. For most species, SRA values ranged from 280 to $400 \mathrm{~cm}^{2} \mathrm{~g}^{-1}$ with Acer reaching SRA values of 470 to $515 \mathrm{~cm}^{2} \mathrm{~g}^{-1}$. Fagus showed a significantly higher SRA in DL 2 plots compared to DL 1 and DL 3 plots, while SRA of Tilia was highest in the DL 3 plots. Mean fine root diameter in the class $<2 \mathrm{~mm}$ ranged from 0.35 to $0.60 \mathrm{~mm}$ with highest values measured in Fraxinus. None of the three morphological parameters were significantly affected by tree species diversity with the exception of root diameter of Fagus, which was smaller in the DL 2 than in the DL 1 and DL 3 plots.

Number of root tips and root area index of the stands

The total number of root tips per $\mathrm{m}^{2}$ ground area was similar in the DL 1 and DL 2 plots (about $1.2 \times 10^{7}$ tips $^{-2}$ ) (Fig. 4a), but as low as $0.8 \times 10^{7}$ tips $\mathrm{m}^{-2}$ in the DL 3 plots. Although Fraxinus and Tilia were co-dominant with Fagus in the DL 2 plots, root tips of Fagus were the most abundant

Table 3 Ratio of the percent contribution of a species in fine root biomass to its percent contribution to stand basal area and fine root biomass/ necromass ratio in the plots of the three diversity levels $(n=4)$

\begin{tabular}{|c|c|c|c|c|c|c|}
\hline \multirow[t]{2}{*}{ Species } & \multicolumn{3}{|c|}{ Fine root biomass/basal area ratio $\left(\% \%^{-1}\right)$} & \multicolumn{3}{|c|}{ Fine root biomass/necromass ratio $\left(\mathrm{g} \mathrm{g}^{-1}\right)$} \\
\hline & DL 1 & DL 2 & DL 3 & DL 1 & DL 2 & DL 3 \\
\hline Fagus sylvatica & $1.0 \pm 0.03 \alpha$ & $0.7 \pm 0.1$ a $\beta$ & $0.6 \pm 0.2$ a $\beta$ & $1.6 \pm 0.3 \mathrm{a} \alpha$ & $1.8 \pm 0.2 \mathrm{a} \alpha$ & $2.6 \pm 0.9 \mathrm{a} \alpha$ \\
\hline Fraxinus excelsior & & $1.6 \pm 0.4 \mathrm{a} \alpha$ & $1.8 \pm 0.5 \mathrm{bc} \alpha$ & & $1.4 \pm 0.3 \mathrm{a} \alpha$ & $1.5 \pm 0.2 \mathrm{a} \alpha$ \\
\hline Tilia sp. & & $1.4 \pm 0.4 \mathrm{a} \alpha$ & $0.9 \pm 0.2 \mathrm{a} \alpha$ & & $1.7 \pm 0.5 \mathrm{a} \alpha$ & $2.4 \pm 0.4 \mathrm{a} \alpha$ \\
\hline Acer sp. & & $0.8 \pm 0.2 \mathrm{a} \alpha$ & $1.8 \pm 0.1 \mathrm{c} \beta$ & & $1.1 \pm 0.1 \mathrm{a} \alpha$ & $3.5 \pm 1.3 \mathrm{a} \alpha$ \\
\hline Carpinus betulus & & & $1.1 \pm 0.2 \mathrm{ac}$ & & & $3.6 \pm 1.4 \mathrm{a} \alpha$ \\
\hline Other species & & & $0.5 \pm 0.3 \mathrm{ab}$ & & & $7.0 \pm 6.0 \mathrm{a} \alpha$ \\
\hline Stand total & - & - & - & $1.5 \pm 0.3 \mathrm{a} \alpha$ & $1.5 \pm 0.2 \mathrm{a} \alpha$ & $2.1 \pm 0.5 \mathrm{a} \alpha$ \\
\hline
\end{tabular}

Given are means \pm SE. Fine root data refer to soil profile totals $(0-40 \mathrm{~cm}$ depth). Different letters indicate significant differences between species (Latin letters) or diversity levels (Greek letters); $P<0.05$. Other species refers to mean values of Prunus avium, Ulmus glabra, and Quercus sp. present with low abundance in the stands 
Table 4 Vertical change in the fine root density of different species with soil depth

\begin{tabular}{llll}
\hline Species & DL 1 & DL 2 & DL 3 \\
\hline Fagus sylvatica & $0.94 \pm 0.007 \propto$ & $0.94 \pm 0.002 \mathrm{a} \alpha$ & $0.93 \pm 0.02 \mathrm{a} \alpha$ \\
Fraxinus excelsior & $0.92 \pm 0.005 \mathrm{ab} \alpha$ & $0.92 \pm 0.004 \mathrm{a} \alpha$ \\
Tilia sp. & $0.92 \pm 0.002 \mathrm{ab} \alpha$ & $0.93 \pm 0.006 \mathrm{a} \alpha$ \\
Acer sp. & $0.91 \pm 0.008 \mathrm{~b} \alpha$ & $0.92 \pm 0.008 \mathrm{a} \alpha$ \\
Carpinus betulus & & $0.95 \pm 0.008 \mathrm{a}$ \\
\hline
\end{tabular}

The extent of fine root biomass decrease with depth is indicated by the $\beta$ values of the equation $y=1-\beta^{d}$ with $y=$ cumulative fine root biomass fraction in $\mathrm{g} \mathrm{m}^{-2}$ and $d=$ soil depth (see Gale and Grigal 1987) for the tree species in plots of the three diversity levels. Given are means \pm SE of four plot replicates per diversity level and 24 sampling locations per plot. Different letters indicate significant differences $(P<0.05)$ between diversity levels for each species (Greek letters) and between species for each diversity level (lower case Latin letters)

tip species not only in DL 1, but also in the DL 2 plots. In the DL 3 plots, root tips of Tilia were most abundant followed by those of Fagus, Acer, and Carpinus. Root tips of Fraxinus accounted for only $4 \%$ of the total number of root tips in the DL 3 stands.

RAI values ranged from 12 to $13 \mathrm{~m}^{2} \mathrm{~m}^{-2}$ among the stand types (Fig. 4b). Fagus and Fraxinus roots accounted for the major part (82\%) of total RAI in the DL 2 plots. In the DL 3 plots, Tilia and Fraxinus contributed the highest proportion (32\% and 26\%) of RAI, followed by Acer (20\%), Fagus (11\%), and Carpinus (10\%).

\section{Discussion}

Fine root biomass in stands with low and high species diversity

A main objective of our study was to test the hypothesis that species-rich mature forests exhibit higher fine root biomasses than species-poor stands which might give hints on 'below-ground overyielding'. Commonly, the term 'overyielding' is used to characterize a situation where species-rich plant communities are more productive than assemblies comprised of a smaller number of species or monospecific stands (Fridley 2001; Hooper and Dukes 2004; Hooper et al. 2005; Hector 2006). The vast majority of studies on overyielding effects have focused on the above-ground production of plant communities or on bulk above-ground biomass as a proxy for above-ground productivity. 'Overyielding' in terms of above-ground productivity or standing biomass has been proven for certain forests (e.g., Morgan et al. 1992; Erskine et al. 2006). In contrast, systematic investigations on 'below-ground overyielding' in terms of diversity effects on biomass and production of the root system in forests are missing. Such

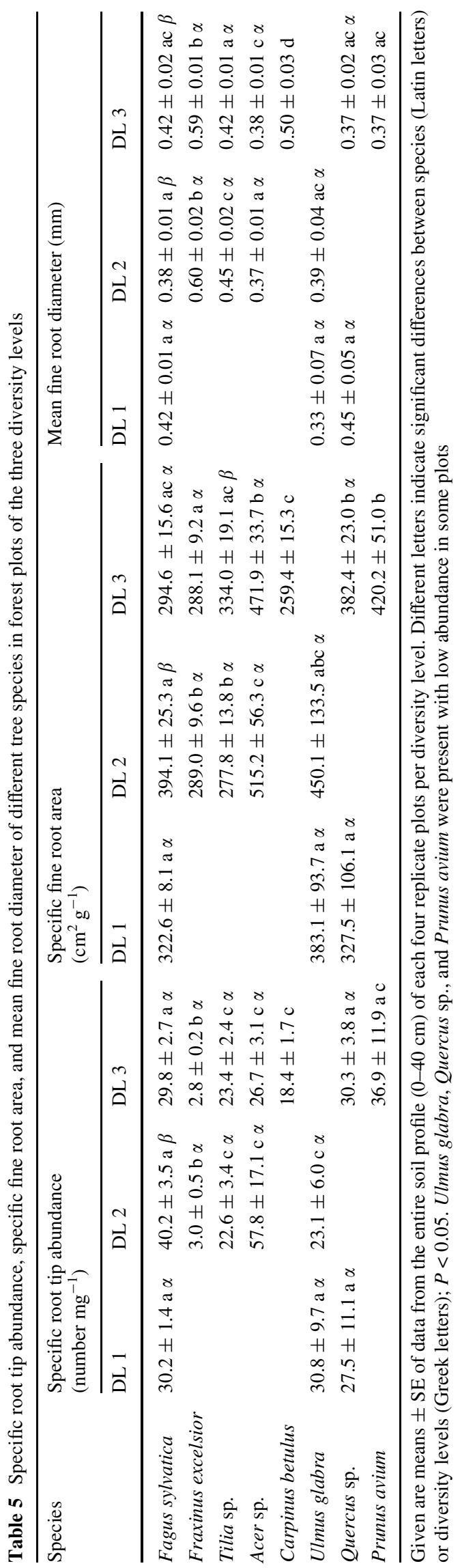


Fig. 4 Root tip abundance (a) and root area index (b) in forest plots of the three diversity levels $(D L)$. Given are means $\pm \mathrm{SE}$ of each four replicate plots per diversity level $(n=24$ sampling locations per plot, soil depth 0 $40 \mathrm{~cm}$ ). Different letters indicate significant differences between diversity levels; $P<0.05$. Others refers to Acer campestre, Prunus avium, Ulmus glabra, and Quercus sp.
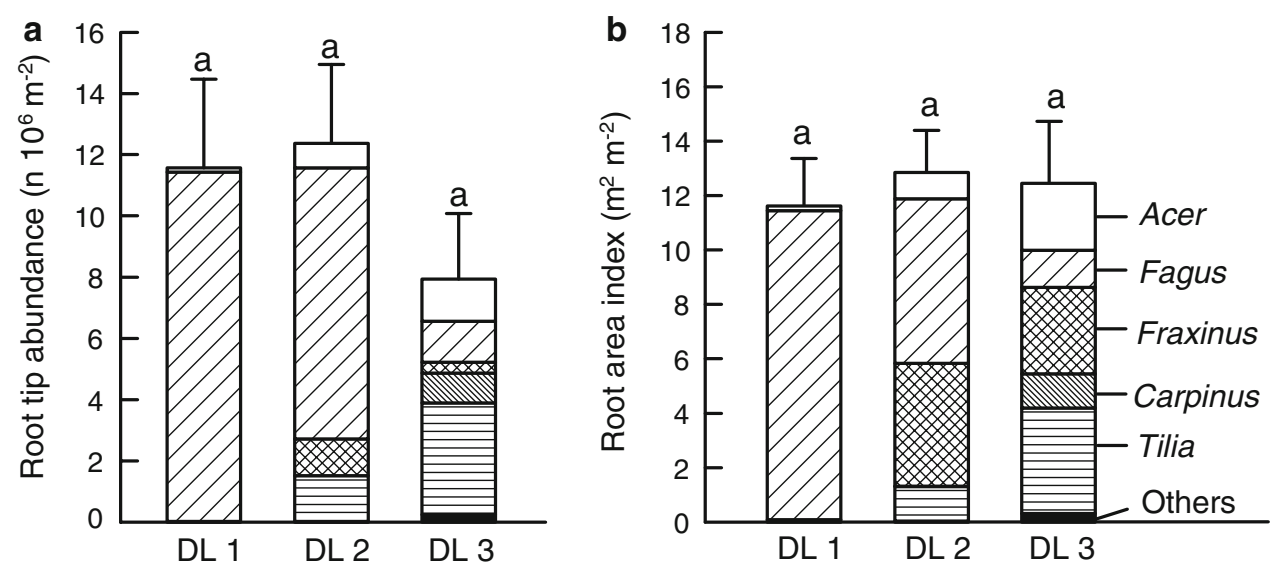

'below-ground overyielding' in terms of higher fine root biomass in mixed forests could result from inherent differences in the species' rooting patterns which lead to a deeper extension or a higher density of the fine root system in mixed as compared to pure stands (Curt and Prevosto 2003; Legare et al. 2005; Jose et al. 2006). On the other hand, if root competition between different species would favor spatial niche differentiation between the root systems of the present species, adaptive growth processes could also result in a higher below-ground biomass following from the exploration of empty space in the rooting environment. Spatial compartmentalization could reduce interspecific root competition and lead to complementary use of water and nutrients in the soil. Moreover, biotic interactions between plants, animals, and microorganisms that may facilitate the coexistence of plant species is expected to increase with increasing plant diversity (e.g., Blair et al. 1990; van der Heijden and Cornelissen 2002; Quested et al. 2005).

In contradiction to our first hypothesis, fine root biomass of the 12 investigated forest stands did not differ significantly between plots dominated by five tree species, three species, and almost pure beech forests. This finding is surprising since marked effects of increasing plant diversity on ecosystem functions are expected particularly in plant communities with relatively small numbers of species (Vitousek and Hooper 1993; Jolliffe 1997). Moreover, the absence of a diversity effect on fine root biomass contrasts with notable differences in the above-ground structure of the DL 1, DL 2, and DL 3 stands as indicated by different fine root biomass/basal area ratios of several species among these stands. Analysis of the depth distribution patterns of the fine roots revealed that the vertical stratification of the fine root systems of the different species was very similar. All species showed a strong exponential decrease of fine root biomass with soil depth, with $63-77 \%$ of total fine root biomass being concentrated in the uppermost $20 \mathrm{~cm}$ of the soil irrespective of species diversity in the stands. This was confirmed by calculating the degree of vertical fine root biomass decrease of the tree species present in the stands as indicated by the $\beta$ values of the regression equation $y=1-\beta^{d}$ introduced by Gale and Grigal (1987). The obtained $\beta$ values indicate a rather superficial rooting pattern of all species in the plots of different tree species diversity. According to these results, a pronounced segregation of the fine root systems of the co-occurring tree species did not exist in the stands.

Avoidance of competition could be one cause of a vertical stratification of root systems in species-rich stands. By comparing monocultures and mixtures of the same two species, Schmid and Kazda (2002) found different vertical fine root distributions in mono-specific and mixed spruce and beech stands, and Hendriks and Bianchi (1995) reported similar results for pure and mixed stands of Douglas fir and beech. For mixed stands of deciduous tree species, Büttner and Leuschner (1994) also showed that the vertical rooting patterns of beech and oak differed between the species and that the cause was most likely asymmetric root competition (see also Hertel 1999; Leuschner et al. 2001). Rust and Savill (2000) obtained similar results for competing beech and ash. Hence, it is surprising that a corresponding vertical stratification of the fine root mass of the different species did not occur in the DL 2 and DL 3 stands of the Hainich forest. Assuming that below-ground competition is the cause of root system segregation, one may expect that competition intensity is less in soils with high nutrient availability as in the Hainich forest, thus reducing the benefit of avoiding competition through niche differentiation.

The stands in the Hainich forest contained relatively high amounts of fine root biomass, in particular in the mixed stands. For monospecific Fagus sylvatica forests on fertile soils, results of Bauhus and Bartsch (1996), Hertel (1999), Leuschner et al. (2004), and Bolte and Villanueva (2006) indicate a mean fine root biomass of $437 \mathrm{~g} \mathrm{~m}^{-2}$ in the soil profile which is very close to the values measured in the monospecific beech stands (DL 1) in our study. On the other hand, for species-rich temperate broad-leaved forest, a mean fine root biomass of about $400 \mathrm{~g} \mathrm{~m}^{-2}$ was 
calculated from the literature data which is less than the $477 \mathrm{~g} \mathrm{~m}^{-2}$ in the mixed DL 2 and DL 3 stands in the Hainich forest (Table 6). Particularly small fine root biomass values were reported for mixed deciduous forests in Central Europe. With $180 \mathrm{~g} \mathrm{~m}^{-2}$ in a four-species oak-hornbeam forest, $172 \mathrm{~g} \mathrm{~m}^{-2}$ in a Quercus-Tilia forest, and only $59 \mathrm{~g} \mathrm{~m}^{-2}$ in a six-species forest on a boulder slope, these forests showed much lower fine root biomasses than our study plots. Moreover, the majority of soil samples from the mixed Hainich forest plots contained fine roots of two or three tree species indicating that interspecific competition must be omnipresent. Further, our data show that it may be important to consider the spatial scale on which possible diversity effects on root biomass are to be analyzed: while fine root biomass was found to be independent of tree species diversity on the stand level, we detected a higher fine root biomass with a higher number of species present when individual surface soil cores were analyzed. However, this was only true for soil samples containing more than three species, which represented only $10 \%$ of all samples. Thus, even if 'below-ground overyielding' in terms of root biomass does exist in the local soil patch, this effect seems to disappear at the stand level because samples with more than three species are uncommon. We speculate that the clayey soil with a high resistance to root penetration may be one reason for the similar vertical root distribution patterns of the different tree species in the Hainich stands, making vertical root segregation and biomass overyielding in mixed stands improbable in these soils. Clearly, standing fine root biomass may be a poor indicator of fine root production, which is a more decisive parameter to be quantified for an assessment of below-ground 'overyielding' phenomena.

Differences in fine root morphology between tree species and between pure and mixed stands

Fine root biomass values may not accurately indicate the capacity of roots for water and nutrient uptake (e.g., Lehmann 2003). Roots in different soil depths can show different physiological activities (Fitter 1996; Pregitzer et al. 1998), and root morphology and age can also cause functional differences between fine root populations within a fine root system (Olsthoorn 1991; Finer et al. 1997; Leuschner et al. 2004). Functionally important morphological parameters are root diameter distribution, specific root area (SRA), and specific root tip abundance (Reich et al. 1998; Bauhus and Messier 1999; Majdi et al. 2001; Pregitzer et al. 2002; Comas and Eissenstat 2004; Withington et al. 2006; Ostonen et al. 2007). In addition, differences in root function associated with the type of mycorrhizal infection (ECM vs. VA) may also affect root activity in species-rich temperate broad-leaved forests.

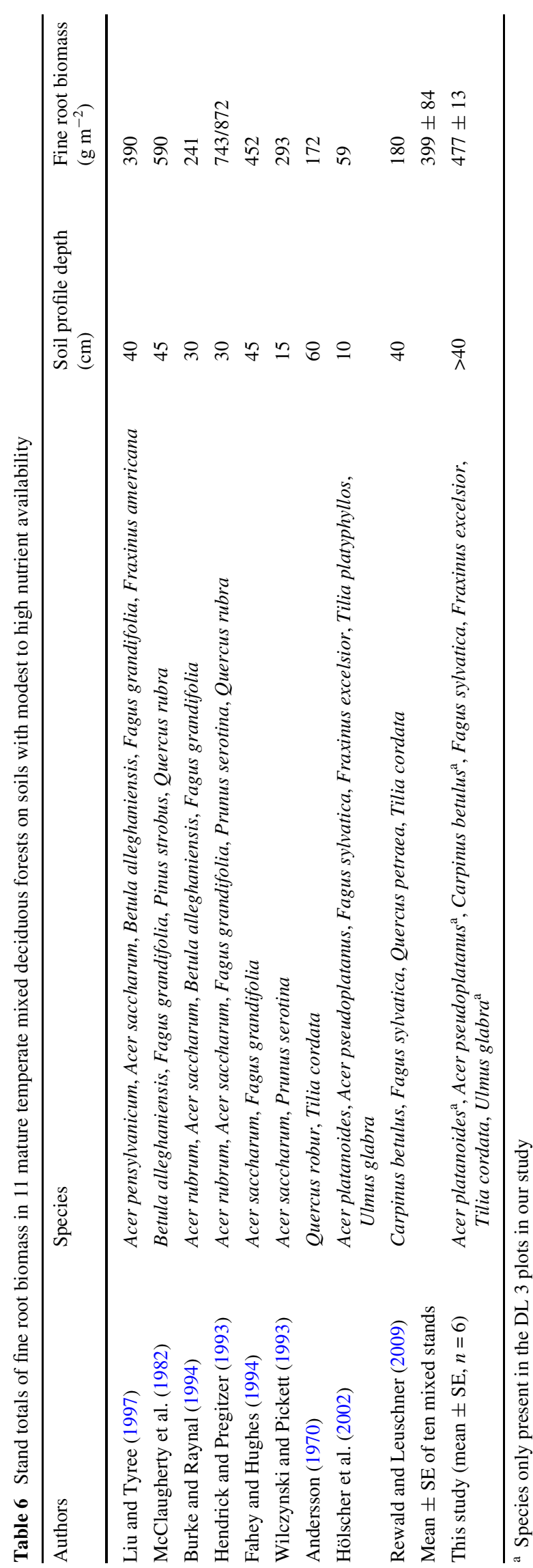


Our study revealed some marked differences in fine root morphological traits between the co-occurring species. Interestingly, there were no systematic differences in fine root morphology between tree species infected by ectomycorrhiza-forming fungi (Fagus, Tilia, Carpinus, Ulmus, Quercus, Prunus) and tree species with arbuscular mycorrhiza (Fraxinus and Acer). On the contrary, the VAinfected genera Fraxinus and Acer showed the two most dissimilar fine root architectures, with Acer (A. platanoides and A. pseudoplatanus) exhibiting fine roots of particularly small diameter, large SRA and high specific root tip abundance, while Fraxinus possesses fine roots with large diameters, small SRAs and low specific root tip abundance. The ECM-infected species were less variable in their fine root morphological traits, ranging with their values between the two VA-infected species. Data on fine root morphology of temperate broad-leaved tree species are rare: Withington et al. (2006) found similar fine root diameter distributions in Fagus and Tilia, but larger fine root diameters in Acer species, as were found in our study. The SRA records for Tilia, Fagus, Fraxinus, Acer, and Ulmus in the study of Hölscher et al. (2002) were somewhat lower than our results, but confirmed the large difference between the two VA-infected genera Acer and Fraxinus. Data on specific root tip abundance in fine roots of different deciduous tree species are virtually missing in the literature.

Given the apparent species-specific differences in root morphology between different co-occurring tree species, effects of altered tree species diversity on fine root morphology in general could not be detected in our study. Exceptions were only found in Fagus fine roots that showed smaller fine root diameters and higher specific root tip abundances and SRA values in DL 2 plots than in the monospecific beech plots (DL 1). Similarly, Tilia fine roots showed higher SRA values in the species-rich DL 3 plots than in DL 2 plots, while root diameter and root tip frequency remained unchanged. The overall lack of changes in fine root morphology in response to the presence of allospecific competitors is surprising, since several authors have emphasized the meaning of architectural plasticity versus allocational plasticity as an important adaptation mode to variable growth conditions (e.g., Bauhus and Messier 1999; Curt and Prevosto 2003). Ostonen et al. (2007), by referring to the optimality theory in plant ecology (Bloom et al. 1985; Eissenstat 1992), identified two main strategies of tree fine roots to adapt to different regimes of soil nutrient supply: trees could either enhance their carbon investment to increase the fine root biomass (and root length) or increase their nutrient uptake efficiency by changes in root morphology to form fine roots of higher SRA. Similar strategies have also been suggested to explain differences in root competition ability of different tree species (Bauhus and Messier 1999; Curt and Prevosto 2003).
Hence, the observed changes in fine root morphology of Fagus and Tilia between species-poor and species-rich stands in our study may represent responses to a higher interspecific competition intensity in the DL 2 and DL 3 plots. A similar result has been reported by Bolte and Villanueva (2006) for Fagus fine roots when beech grew in mixture with Norway spruce. On the other hand, for pure Fagus stands at sites differing in soil fertility, Leuschner et al. (2004) reported that fine root morphology remained nearly unaffected by differences in soil acidity and nutrient concentration.

Not only changes in root morphology might help trees to optimize their cost-benefit ratio of fine roots, but differences in lifespan of the roots may be as crucial in this context (Eissenstat and Yanai 1997; Eissenstat et al. 2000; Withington et al. 2006). Bauhus and Messier (1999) concluded that the thicker and less ramified fine roots of conifers (which in this sense resemble the Fraxinus fine roots of our study) might live longer than fine roots of deciduous trees and, hence, may not necessarily be more cost-intensive. However, in the absence of direct observations on root dynamics, any differences in fine root longevity remain speculative.

Although fine root morphology differed among the tree species, it had no significant influence on stand totals of fine root biomass. Root tip abundance (number of root tips per $\mathrm{m}^{2}$ ground area) tended to be lower in the species-rich DL 3 plots due to the low specific root tip abundance of Fraxinus, but this finding was not statistically significant. The root surface area indices of the stands, on the other hand, were almost identical between the diversity levels but high in comparison to literature data (see Jackson et al. 1997; Leuschner et al. 2004), thus confirming that the upper soil horizons in our study plots were densely exploited by fine roots independently of the composition of the tree layer.

\section{Conclusions}

Our two hypotheses were not supported by the data from the 12 deciduous forest stands: the fine root biomass of the stands was not affected by the number of tree species present, which contrasts with the more marked differences in above-ground structure among the stands. It remains unclear as to whether these above-ground/below-ground differences in the response to a variable tree species diversity are a reflection of principal differences in competition mechanisms acting at the canopy and root levels. The lack of vertical niche segregation among the fine root systems of co-occurring species offers an explanation for the fact that fine root biomass at the stand level was not affected by tree species diversity. This does not fully exclude that 'belowground overyielding' does occur in species-rich stands 
since root productivity data are not yet available. Moreover, this finding does not allow for any conclusion on the occurrence of 'overyielding' in terms of bulk above-ground biomass or productivity in these stands. The identity of co-occurring tree species had no significant influence on the morphology of the roots; root diameter distribution, tip frequency, and specific root surface area showed characteristic differences among the species, but were more or less similar in monospecific and species-rich stands. Thus, the tree species were rather conservative with regard to the morphological plasticity of their fine roots and also the vertical fine root distribution patterns. This held true although the recorded fine root biomasses as well as the total root surface areas of the stands indicate rather high fine root densities that should cause intense below-ground competition. However, it remains open whether species-specific differences in fine root lifespan affect the below-ground productivity of the studied stands.

Acknowledgments This study was funded by the German Research Foundation (DGF) in the context of the Research Training Group 1086 'The role of biodiversity for biogeochemical cycles and biotic interactions in temperate deciduous forests'. We are very grateful to the National Park administration for the permission to conduct the study in the Hainich National Park. Data of forest stand parameters were kindly provided by Mascha Brauns, Anja Guckland, Andreas Mölder and Inga Schmidt.

Open Access This article is distributed under the terms of the Creative Commons Attribution Noncommercial License which permits any noncommercial use, distribution, and reproduction in any medium, provided the original author(s) and source are credited.

\section{References}

Andersson F (1970) Ecological studies in a Scandinavian woodland and meadow area, southern Sweden. 2. Plant biomass, primary production and turnover of organic matter. Bot Notiser 123:8-51

Bauhus J, Bartsch N (1996) Fine-root growth in beech (Fagus sylvatica) forest gaps. Can J For Res 26:2153-2159

Bauhus J, Messier C (1999) Soil exploitation strategies of fine roots in different tree species of the southern boreal forest of eastern Canada. Can J For Res 29:260-273

Bauhus J, Khanna PK, Menden N (2000) Aboveground and belowground interactions in mixed plantations of Eucalyptus globulus and Acacia mearnsii. Can J For Res 30:1886-1894

Berish CW, Ewel JJ (1988) Root development in simple and complex tropical successional ecosystems. Plant Soil 106:73-84

Blair JM, Parmelee RW, Beare MH (1990) Decay-rates, nitrogen fluxes, and decomposer communities of single-species and mixedspecies foliar litter. Ecology 71:1976-1985

Bloom AJ, Chapin FS, Mooney HA (1985) Resource limitations in plants-an economic analogy. Annu Rev Ecol Syst 16:363-392

Bolte A, Villanueva I (2006) Interspecific competition impacts on the morphology and distribution of fine roots in European beech (Fagus sylvatica L.) and Norway spruce (Picea abies (L.) Karst.). Eur J For Res 125:15-26

Brown AFH (1992) Functioning of mixed-species stands at Gisburn, N.W. England. In: Cannell MGR, Malcolm DC, Robertson PA (eds) The ecology of mixed-species stands of trees. Blackwell, Oxford, pp 125-150

Burke MK, Raynal DJ (1994) Fine root growth phenology, production, and turnover in a northern hardwood forest ecosystem. Plant Soil 162:135-146

Büttner V, Leuschner C (1994) Spatial and temporal patterns of fineroot abundance in a mixed oak beech forest. For Ecol Manage 70:11-21

Comas LH, Eissenstat DM (2004) Linking fine root traits to maximum potential growth rate among 11 mature temperate tree species. Funct Ecol 18:388-397

Cuevas E, Brown S, Lugo AE (1991) Aboveground and belowground organic-matter storage and production in a tropical pine plantation and a paired broadleaf secondary forest. Plant Soil 135:257268

Curt T, Prevosto B (2003) Rooting strategy of naturally regenerated beech in silver birch and Scots pine woodlands. Plant Soil 255:265-279

DeAngelis DL, Gardner RH, Shugart HH (1981) Productivity of forest ecosystems studies during IBP: the woodland data set. In: Reichle DE (ed) Dynamic properties of forest ecosystems. Cambridge University Press, Cambridge, pp 567-659

Dybzinski R, Fargione JE, Zak DR, Fornara D, Timan D (2008) Soil fertility increases with plant species diversity in a long-term biodiversity experiment. Oecologia 158:85-93

Eissenstat DM (1992) Costs and benefits of constructing roots of small diameter. J Plant Nutr 15:763-782

Eissenstat DM, Yanai RD (1997) The ecology of root lifespan. Adv Ecol Res 27:1-60

Eissenstat DM, Wells CE, Yanai RD, Whitbeck JL (2000) Building roots in a changing environment: implications for root longevity. New Phytol 147:33-42

Enquist BJ, Niklas KJ (2001) Invariant scaling relations across treedominated communities. Nature 410:655-660

Erskine PD, Lamb D, Bristow M (2006) Tree species diversity and ecosystem function: can tropical multi-species plantations generate greater productivity? For Ecol Manage 233:205-210

Fahey TJ, Hughes JW (1994) Fine root dynamics in a northern hardwood forest ecosystem, Hubbard Brook Experimental Forest, NH. J Ecol 82:533-548

FAO (2006) World reference base for soil resources 2006. World soil resources reports 103. FAO, Rome

Finer L, Messier C, DeGrandpre L (1997) Fine-root dynamics in mixed boreal conifer-broad-leafed forest stands at different successional stages after fire. Can J For Res 27:304-314

Fitter A (1996) Characteristics and functions of root systems. In: Waisel Y, Eshel A, Kafkafi U (eds) Plant roots: the hidden half. Dekker, New York, pp 1-20

Fogel R, Hunt G (1983) Contribution of mycorrhizae and soil fungi to nutrient cycling in a Douglas-fir ecosystem. Can J For Res $13: 219-232$

Fridley JD (2001) The influence of species diversity on ecosystem productivity: how, where, and why? Oikos 93:514-526

Gale MR, Grigal DF (1987) Vertical root distributions of northern tree species in relation to successional status. Can J For Res 17:829-834

Guckland A, Brauns M, Flessa H, Thomas FM, Leuschner C (2009) Acidity, nutrient stocks and organic matter content in soils of a temperate deciduous forest with different abundance of European beech (Fagus sylvatica L.). J Plant Nutr Soil Sci (in press)

Hector A (2001) Biodiversity and functioning of grassland ecosystems: multi-site comparison. In: Kinzig AP, Tilman D, Pacala SW (eds) The functional consequences of biodiversity: empirical progress and theoretical extensions. Princton University Press, Princeton, pp 71-95

Hector A (2006) Overyielding and stable species coexistence. New Phytol 172:1-3 
Hector A, Schmid B, Beierkuhnlein C, Caldeira MC, Diemer M, Dimitrakopoulos PG, Finn JA, Freitas H, Giller PS, Good J, Harris R, Hogberg P, Huss-Danell K, Joshi J, Jumpponen A, Körner C, Leadley PW, Loreau M, Minns A, Mulder CPH, O’Donovan G, Otway SJ, Pereira JS, Prinz A, Read DJ, SchererLorenzen M, Schulze ED, Siamantziouras ASD, Spehn EM, Terry AC, Troumbis AY, Woodward FI, Yachi S, Lawton JH (1999) Plant diversity and productivity experiments in European grasslands. Science 286:1123-1127

Hendrick RL, Pregitzer KS (1993) The dynamics of fine root length, biomass, and nitrogen content in two northern hardwood ecosystems. Can J For Res 23:2507-2520

Hendriks CMA, Bianchi FJJA (1995) Root density and root biomass in pure and mixed forest stands of Donglas-fir and Beech. Neth J Agric Sci 43:321-331

Hertel D (1999) Das Feinwurzelsystem von Rein- und Mischbeständen der Rotbuche: Struktur, Dynamik und interspezifische Konkurrenz. Dissertationes Botanicae 317. Gebrüder Borntraeger, Berlin

Hölscher D, Hertel D, Leuschner C, Hottkowitz M (2002) Tree species diversity and soil patchiness in a temperate broad-leaved forest with limited rooting space. Flora 197:118-125

Hooper DU, Dukes JS (2004) Overyielding among plant functional groups in a long-term experiment. Ecol Lett 7:95-105

Hooper DU, Vitousek PM (1997) The effects of plant composition and diversity on ecosystem processes. Science 277:1302-1305

Hooper DU, Chapin FS, Ewel JJ, Hector A, Inchausti P, Lavorel S, Lawton JH, Lodge DM, Loreau M, Naeem S, Schmid B, Setälä H, Symstad AJ, Vandermeer J, Wardle DA (2005) Effects of biodiversity on ecosystem functioning: a consensus of current knowledge. Ecol Monogr 75:3-35

Jackson RB, Canadell J, Ehleringer JR, Mooney HA, Sala OE, Schulze ED (1996) A global analysis of root distributions for terrestrial biomes. Oecologia 108:389-411

Jackson RB, Mooney HA, Schulze ED (1997) A global budget for fine root biomass, surface area, and nutrient contents. Proc Natl Acad Sci USA 94:7362-7366

Jolliffe PA (1997) Are mixed populations of plant species more productive than pure stands? Oikos 80:595-602

Jose S, Williams R, Zamora D (2006) Belowground ecological interactions in mixed-species forest plantations. For Ecol Manage 233:231-239

Joshi J, Matthies D, Schmid B (2000) Root hemiparasites and plant diversity in experimental grassland communities. J Ecol 88:634-644

Keyes MR, Grier CC (1981) Above- and below-ground net production in 40-year old Douglas-fir stands on low and high productivity sites. Can J For Res 11:599-605

Legare S, Bergeron Y, Pare D (2005) Effect of aspen (Populus tremuloides) as a companion species on the growth of black spruce (Picea mariana) in the southwestern boreal forest of Quebec. For Ecol Manage 208:211-222

Lehmann J (2003) Subsoil root activity in tree-based cropping systems. Plant Soil 255:319-331

Leuschner C, Hertel D (2003) Fine root biomass of temperate forests in relation to soil acidity and fertility, climate, age and species. Prog Bot 64:405-438

Leuschner C, Hertel D, Coners H, Büttner V (2001) Root competition between beech and oak: a hypothesis. Oecologia 126:276-284

Leuschner C, Hertel D, Schmid I, Koch O, Muhs A, Hölscher D (2004) Stand fine root biomass and fine root morphology in old-growth beech forests as a function of precipitation and soil fertility. Plant Soil 258:43-56

Liu X, Tyree MT (1997) Root carbohydrate reserves, mineral nutrient concentrations and biomass in a healthy and a declining sugar maple (Acer saccharurn) stand. Tree Physiol 17:179-185

Lohmus K, Oja T, Lasn R (1989) Specific root area-a soil characteristic. Plant Soil 119:245-249
Loreau M, Hector A (2001) Partitioning selection and complementarity in biodiversity experiments. Nature 412:72-76

Majdi H, Damm E, Nylund JE (2001) Longevity of mycorrhizal roots depends on branching order and nutrient availability. New Phytol 150:195-202

McClaugherty CA, Aber JD, Melillo JM (1982) The role of fine roots in the organic matter and nitrogen budgets of two forested ecosystems. Ecology 63:1481-1490

Mölder A, Bernhardt-Römermann M, Schmidt W (2006) Forest ecosystem research in Hainich National Park (Thuringia): first results on flora and vegetation in stands with contrasting tree species diversity. Waldökologie 3:83-99

Mölder A, Bernhardt-Römermann M, Schmidt W (2008) Herb-layer diversity in deciduous forests: raised by tree richness or beaten by beech? For Ecol Manage 256:272-281

Morgan JL, Campbell JM, Malcolm DC (1992) Nitrogen relations of mixed-species stands on oligotrophic soils. In: Cannell MGR, Malcolm DC, Robertson PA (eds) The ecology of mixed-species stands of trees. Blackwell, London, pp 65-85

Olsthoorn AFM (1991) Fine root density and root biomass of 2 Douglas-fir stands on sandy soils in the Netherlands. 1. Root biomass in early summer. Neth J Agric Sci 39:49-60

Ostonen I, Lohmus K, Helmisaari HS, Truu J, Meel S (2007) Fine root morphological adaptations in Scots pine, Norway spruce and silver birch along a latitudinal gradient in boreal forests. Tree Physiol 27:1627-1634

Parrish JAD, Bazzaz FA (1976) Underground niche separation in successional plants. Ecology 57:1281-1288

Persson H (1978) Root dynamics in a young Scots pine stand in Central Sweden. Oikos 30:508-519

Pregitzer KS, Laskowski MJ, Burton AJ, Lessard VC, Zak DR (1998) Variation in sugar maple root respiration with root diameter and soil depth. Tree Physiol 18:665-670

Pregitzer KS, DeForest JL, Burton AJ, Allen MF, Ruess RW, Hendrick RL (2002) Fine root architecture of nine North American trees. Ecol Monogr 72:293-309

Pretzsch H (2005) Diversity and productivity in forests: evidence from long-term experimental plots. In: Scherer-Lorenzen M, Körner Ch, Schulze E-D (eds) Forest diversity and function: temperate and boreal systems. Ecological studies, vol 176. Springer, Berlin, pp 41-64

Quested HM, Callaghan TV, Cornelissen JHC, Press MC (2005) The impact of hemiparasitic plant litter on decomposition: direct, seasonal and litter mixing effects. J Ecol 93:87-98

Reich PB, Walters MB, Tjoelker MG, Vanderklein D, Buschena C (1998) Photosynthesis and respiration rates depend on leaf and root morphology and nitrogen concentration in nine boreal tree species differing in relative growth rate. Funct Ecol 12:395-405

Rewald B, Leuschner C (2009) Belowground competition in a broadleaved temperate mixed forest-pattern analysis and experiments in a four-species stand. Eur J For Res (in press)

Rust S, Savill PS (2000) The root systems of Fraxinus excelsior and Fagus sylvatica and their competitive relationships. Forestry 73:499-508

Scherer-Lorenzen M, Körner Ch, Schulze E-D (2005) The functional significance of forest diversity: a synthesis. In: Scherer-Lorenzen M, Körner Ch, Schulze E-D (eds) Forest diversity and function: temperate and boreal systems. Ecological studies, vol 176. Springer, Berlin, pp 377-390

Scherer-Lorenzen M, Schulze E-D, Don A, Schumacher J, Weller E (2007) Exploring the functional significance of forest diversity: a new long-term experiment with temperate tree species (BIOTREE). Perspect Plant Ecol 9:53-70

Schlesinger WH (1997) Biogeochemistry. An analysis of global change. Academic Press, San Diego 
Schmid I (2002) The influence of soil type and interspecific competition on the fine root system of Norway spruce and European beech. Basic Appl Ecol 3:339-346

Schmid I, Kazda M (2002) Root distribution of Norway spruce in monospecific and mixed stands on different soils. For Ecol Manage 159:37-47

Schmid B, Joshi J, Schläpfer F (2001) Empirical evidence for biodiversity-ecosystem functioning relationships. In: Kinzig AP, Pacala SW, Tilman D (eds) The functional consequences of biodiversity: empirical progress and theoretical extensions. Princton University Press, Princton, pp 120-150

Smith FW, Long JN (1992) A comparison of stemwood production in monocultures and mixtures of Pinus contorta var. latifolia and Abies lasiocarpa. In: Cannell MGR, Malcolm DC, Robertson PA (eds) The ecology of mixed-species stands of trees. Blackwell, London, pp 87-98

Spehn EM, Joshi J, Schmid B, Alphei J, Körner C (2000) Plant diversity effects on soil heterotrophic activity in experimental grassland systems. Plant Soil 224:217-230

Szwagrzyk J, Gazda A (2007) Above-ground standing biomass and tree species diversity in natural stands of Central Europe. J Veg Sci 18:555-562

Tilman D, Wedin D, Knops J (1996) Productivity and sustainability influenced by biodiversity in grassland ecosystems. Nature 379:718-720 van der Heijden MGA, Cornelissen JHC (2002) The critical role of plant-microbe interactions on biodiversity and ecosystem functioning: arbuscular mycorrhizal associations as an example. In: Loreau M, Naeem S, Inchausti P (eds) Biodiversity and ecosystem functioning: synthesis and perspectives. Oxford University Press, London, pp 181-194

van Praag HJ, Sougnezremy S, Weissen F, Carletti G (1988) Root turnover in a beech and a spruce stand of the Belgian Ardennes. Plant Soil 105:87-103

Vila M, Vayreda J, Gracia C, Ibanez JJ (2003) Does tree diversity increase wood production in pine forests? Oecologia 135:299-303

Vitousek PM, Hooper DU (1993) Biological diversity and terrestrial ecosystem biogeochemistry. In: Schulze E-D, Mooney HA (eds) Biodiversity and ecosystem function. Springer, Berlin, pp 3-14

Wilczynski CJ, Pickett STA (1993) Fine root biomass within experimental canopy gaps: evidence for a below-ground gap. J Veg Sci 4:571-574

Withington JM, Reich PB, Oleksyn J, Eissenstat DM (2006) Comparisons of structure and life span in roots and leaves among temperate trees. Ecol Monogr 76:381-397

Yanai RD (1992) Competitive interactions between Norway spruce and Scots pine at Gisburn Forest, New England. Forestry 65:435451 